\title{
Strategi Pengembangan Usaha Batik untuk Meningkatkan Daya Saing Klaster Batik Batangan
}

\author{
Yahya Adi Surya ${ }^{凶}$ \\ Jurusan Ekonomi Pembangunan,Fakultas Ekonomi, Universitas Negeri Semarang \\ Permalink/DOI: https://doi.org/10.15294/efficient.vii1.27224 \\ Received: July 2017; Accepted: October 2017; Published: January 2018
}

\begin{abstract}
The purpose of this research is to draw industrial development strategy batik to increase the competitiveness of batik cluster Batangan in Batang distric. Methods used in research is quantitative descriptive using three of analysis is descriptive, policy analysis matrix (PAM) and analytic hierarchy process (AHP). The research results show obstacles in the development of cluster batik Batangan consisting of five major aspects that is aspects human resources, financial aspects, marketing aspects, raw materials aspects and technology aspects. Analysis pam obtained the result that cluster batik Batangan having competitiveness through the comparative excellences ( a value o.25) or competitive advantage ( $a$ value at 0.24 ). The results of analytic hierarchy process obtained development strategy cluster business batik Batangan consisting of five program criteria which are prioritized the first criteria raw materials ( a value weight 0,254), second financial criteria ( $a$ value weight 0,231 ), third criteria technology ( a value weight 0,211 ), fourth criteria human resources ( a value weight 0,193 ) and fifth criteria marketing ( a value weight 0,111 ).
\end{abstract}

Keywords: Development Strategy, Batik Cluster, Analytic Hierarchy Process

\begin{abstract}
Abstrak
Tujuan penelitian ini adalah untuk menyusun strategi pengembangan indutri batik untuk meningkatkan daya saing klaster batik Batangan di Kabupaten Batang. Metode yang digunakan dalam penelitian ini adalah deskriptif kuantitatif dengan menggunakan tiga analisis yaitu deskriptif, Policy Analysis Matrix (PAM) dan Analytic Hierarchy Process (AHP). Hasil penelitian menunjukkan hambatan dalam pengembangan klaster batik Batangan terdiri dari lima aspek yaitu aspek sumber daya manusia, aspek keuangan, aspek pemasaran, aspek bahan baku dan aspek teknologi. Analisis PAM diperoleh hasil bahwa klaster batik Batangan memiliki daya saing melalui keunggulan komparatif (nilai o,25) maupun keunggulan kompetitif (nilai o,24). Hasil Analytic Hierarchy Process diperoleh strategi pengembangan usaha klaster batik Batangan terdiri dari lima kriteria program yang diprioritaskan yaitu pertama kriteria bahan baku (nilai bobot o,254), kedua kriteria keuangan (nilai bobot 0,231), ketiga kriteria teknologi (nilai bobot 0,211), keempat kriteria sumber daya manusia (nilai bobot o,193) dan kelima kriteria pemasaran (nilai bobot o,111).
\end{abstract}

\section{Kata Kunci: Strategi Pengembangan, Kluster Batik, Analytic Hierarchy Process}

How to Cite: Surya, Y. (2018). Strategi Pengembangan Usaha Batik untuk Meningkatkan Daya Saing Klaster Batik Batangan. EFFICIENT Indonesian Journal of Development Economics, 1(1), 86-91. https://doi.org/10.15294/efficient.vii1.27224

(c) 2018 Semarang State University. All rights reserved

\footnotetext{
Alamat Korespondensi :

Alamat: Gedung L2 Lantai 2 FE Unnes

Kampus Sekaran, Gunungpati, Semarang, 50229

E-mail : yahyaadi94@yahoo.co.id
} 


\section{PENDAHULUAN}

Sektor industri mampu mengatasi masalahmasalah perekonomian dengan asumsi sektor industri dapat memimpin sektor-sektor perekonomian lainnya. Sektor industri memiliki kontribusi besar terhadap penerimaan produk domestik bruto Indonesia. Kontribusi tahun 2015 mencapai 20,84\% dari total 8.976,93 miliar PDB Indonesia. Penyerapan tenaga kerja mencapai $11 \%$ total angkatan kerja Indonesia.

Industri kecil dan menengah merupakan salah satu sektor industri yang mampu bertahan pada saat terjadi krisis. Hal ini disebabkan karena industri kecil dan menengah pada umumnya memanfaatkan sumber daya lokal, baik dari sumber daya manusia, modal, bahan baku hingga peralatannya. Ketangguhan dan kreatifitas IKM mampu ditunjukkan pada saat terjadi krisis tahun 1998, dilihat dari jumlah usaha kecil yang meningkat sebesar $0,1 \%$ dan kontribusi terhadap PDB naik sebesar 19,56\% (Hamid, 2005) dalam (Sandriana dkk, 2015).

Namun demikian IKM tidak lepas dari adanya kendala yang dihadapi baik dari internal maupun eksternal. Masalah internal meliputi masalah permodalan, masalah administrasi keuangan, masalah kaderisasi dan masalah pengelolaan tunggal. Sedangkan masalah ekternal meliputi iklim usaha dan keterbatasan sarana prasarana yang dimiliki IKM. (Lestari, 2005).

Jumlah IKM di Provinsi Jawa Tengah pada tahun 2014 mencapai 697.018 unit dengan penyerapan tenaga kerja sejumlah $17,78 \%$ angkatan kerja Provinsi Jawa Tengah. Menurut Deputi Bidang Pengkajian dan Sumber Daya UMKM Kementerian Koperasi dan UMKM, pemerintah daerah dapat meningkatkan daya saing Usaha Kecil dan Menengah untuk menggaet pasar yang lebih luas melalui pengembangan klaster. Klaster merupakan konsentrasi perusahaan-perusahaan yang saling berhubungan dalam bidang tertentu. Konsentrasi perusahaan di suatu wilayah akan mampu menarik calon pembeli. Demikian dengan suplai bahan baku karena permintaan bahan baku besar dari sebuah klaster maka suplier akan cenderung datang dan menawarkan. Klaster juga akan mendorong berkumpulnya tenaga kerja berpengalaman di wilayah tersebut (Hartanto, 2004).

Provinsi Jawa Tengah memiliki 200 klaster yang terdiri dari klaster industri, pertanian dan pariwisata. Salah satu klaster yang memiliki potensi besar yaitu klaster batik. Batik merupakan produk warisan dunia yang dimiliki Indonesia dengan nilai produksi batik pada tahun 2015 mencapai USD 39,4 juta. Sedangkan pada tahun 2011 sampai 2015 nilai pembelian bahan baku meningkat $12,8 \%$ dan nilai tambah batik naik $14,7 \%$.

Terdapat 19 klaster batik di Provinsi Jawa Tengah dengan nilai omset usaha yang terus mengalami peningkatan dari tahun 2010 sampai 2015 kecuali pada klaster batik Grobogan dan klaster batik Batang. Klaster batik Grobogan terjadi penurunan omset usaha pada tahun 2015 yang sebelumnya sebesar 1,32 miliar menjadi 1,20 miliar atau penurunan sebesar 0,12 miliar. Sedangkan pada klaster batik Batang penurunan omset terjadi mulai tahun 2014 dan tahun 2015 dengan masing-masing sebesar 0,05 miliar dan o,82 miliar. Dilihat dari penurunan omset usaha tersebut batik Batang mengalami penurunan yang besar dibandingkan dengan klaster batik Grobogan. 


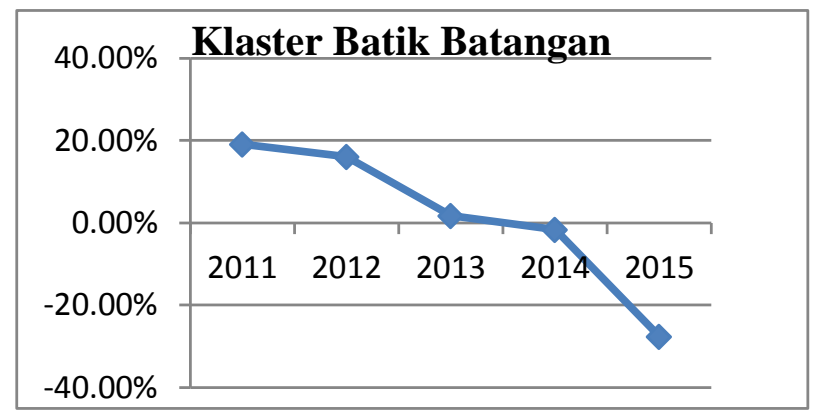

Grafik 1. Perkembangan Omset Klaster Batik Batangan

Sumber: Bappeda Provinsi Jawa Tengah, 2015 (diolah)

Batik Batangan merupakan batik yang dihasilkan di klaster batik Batang. Faktor penunjang perkembangan motif batik Batangan meliputi motif batik khas Batang yang memiliki konsumen ataupun pasar tersendiri dan adanya keinginan masyarakat untuk mempertahankan motif batik khas Batang yang menjadi identitas daerah. Jenis batik yang diproduksi yaitu batik cap dan batik tulis.

Namun dalam aktivitas usaha di klaster batik Batangan mengalami kendala-kendala yang dihadapi. Beberapa kendala yang dihadapi dalam usaha klaster batik Batangan diantaranya dalam pemasaran yaitu masih sulit untuk memperluas daerah pemasaran. Kendala lainnya yaitu pengusaha kesulitan dalam kaderisasi atau sulit untuk mendapatkan tenaga kerja baru serta kesulitan dalam mendapatkan modal usaha.

Penelitian ini bertujuan untuk mendeskripsikanhambatan - hambatan pengembangan usaha, mengetahui daya saing dan merumuskan strategi pengembangan usaha klaster batik Batangan.

\section{METODE PENELITIAN}

Penelitian ini menggunakan metode kualitatif dan kuantitatif. Metode kualitatif digunakan untuk mendeskripsikan hambatanhambatan yang dialami dalam usaha batik klaster batik Batangan. Metode kuantitatif digunakan untuk mengukur besaran daya saing klaster batik Batangan dan merumuskan strategi pengembangan usaha batik Klaster batik Batangan. Jenis data yang digunakan dalam penelitian ini adalah data primer dan data sekunder. Data primer untuk mengetahui hambatan dan daya saing diperoleh dari responden pengusaha batik di klaster batik Batangan serta untuk merumuskan strategi pengembangan usaha diperoleh dari keyperson. Data sekunder diperoleh dari instansi terkait yaitu Badan Pusat Statistik, Badan Perencanaan dan Pembangunan Daerah Provinsi Jawa Tengah serta literatur terkait dalam penelitian ini.

Penelitian ini menggunakan tiga metode analisis yaitu deskriptif, Policy Analysis Matrix (PAM) dan Analisis Hirarki Proses (AHP). Analisis deskriptif digunakan untuk mendeskriptifkan hambatan yang ada di klaster batik Batangan. Analisis PAM digunakan untuk mengetahui daya saing klaster batik Batangan serta analisis AHP untuk merumuskan strategi pengembangan usaha klaster batik Batangan.

Teknik pengumpulan data dalam penelitian ini ada empat cara yaitu: Observasi, Dokumentasi, Wawancara dan Angket. Observasi dilakukan untuk mengetahui hambatan awal yang terjadi di klaster batik Batangan. Dokumentasi dilakukan untuk mendapatkan data tentang PDRB Provinsi Jawa 
Tengah dan Kabupaten Batang serta untuk mendapatkan omset usaha klaster batik di Provinsi Jawa Tengah. Wawancara dilakukan untuk mendapatakan informasi mengenai kendala-kendala yang dihadapi di masing-masing usaha batik klaster batik Batangan dan mendapatkan informasi untuk menghitung daya saing klaster batik Batangan. Angket digunakan untuk mendapatkan data maupun informasi dari seluruh keyperson sebagai langkah merumuskan strategi pengembangan usaha batik di klaster batik Batangan.

\section{HASIL DAN PEMBAHASAN}

\section{Hambatan Usaha pada Klaster batik Batangan}

Setiap aktivitas usaha tidak selamanya berjalan lancar, terkadang terdapat hambatan yang mengganggu jalannya usaha atau menghambat perkembangan usaha. Hasil penelitian menunjukkan hambatan-hambatan yang terdapat pada usaha klaster batik Batangan mencakup lima aspek yaitu aspek sumber daya manusia, aspek pemasaran, aspek keuangan, aspek bahan baku dan aspek teknologi.

Hambatan yang dialami dalam aspek sumber daya manusia yaitu para pengusaha di klaster batik Batangan kesulitan dalam mencari tenaga kerja baru dan kurangnnya skill yang dimilik oleh tenaga kerja. Hambatan dalam aspek pemasaran yaitu sulitnya pengusaha untuk memasarkan hasil produk batik karena kalah bersaing dengan daerah lain. Hambatan dalam aspek keuangan yaitu para pengusaha kesulitan dalam mendapatkan pinjaman sebagai modal usaha. Hambatan dalam aspek bahan baku yaitu semakin mahalnya harga bahan baku dirasakan oleh para pengusaha batik. Hal ini menyebabkan semakin tingginya biaya produksi yang harus dikeluarkan oleh pengusaha batik sedangkan harga jual tidak naik. Hambatan dalam aspek teknologi yaitu biaya-biaya pembuatan alat-alat yang dirasa sangat mahal dan kurangnya inovasiinovasi di dalam pembuatan motif batik.

\section{Daya Saing Klaster Batik Batangan}

Tabel 1. Hasil Analisis Daya Saing Policy Matrix Analysis (PAM) klaster Batik Batangan di Kabupaten Batang Tahun 2017 (Januari-Juni)

\begin{tabular}{lll}
\hline \multirow{3}{*}{ Tahun } & Keunggulan & Keunggulan \\
& Komparatif & Kompetitif \\
\cline { 2 - 3 } & DRC $<1$ & PCR $<1$ \\
$\mathbf{2 0 1 7}$ & $\mathbf{0 , 2 5}$ & $\mathbf{0 , 2 4}$ \\
\hline
\end{tabular}

Sumber: Hasil PAM, diolah

Hasil analisis PAM menunjukkan bahwa klaster batik Batangan memiliki daya saing baik melalui keunggulan komparatif maupun keunggulan kompetitif. Keunggulan kompetitif dianalisis menggunakan indikator Domestic Resources Cost Ratio dengan nilai sebesar 0,25. Kondisi ini menunjukkan bahwa klaster batik Batangan telah efisien dan memiliki keunggulan komparatif. Sedangkan keunggulan kompetitif dianalisis menggunakan indikator Private Cost Ratio dengan nilai sebesar o,24. Hal ini menunjukkan klaster batik Batangan telah mampu menggunakan domestiknya atas harga aktual dan memiliki keunggulan kompetitif.

\section{Strategi Pengembangan Usaha Batik di Klaster Batik Batangan}

Berdasarkan analisis AHP hasil gabungan pendapat keyperson menunjukkan strategi pengembangan usaha klaster batik Batangan dari yang prioritas yaitu pertama kriteria bahan baku (nilai bobot 0,254), kedua kriteria keuangan (nilai bobot 0,231 ), ketiga kriteria teknologi (nilai bobot o,211), keempat kriteria sumber daya manusia (nilai bobot 0,193) dan kelima kriteria pemasaran (nilai bobot 0,111). 
Hasil olah data AHP menentukan kriteria yang menjadi prioritas yang harus diperbaiki dan dilaksanakan untuk mengembangkan usaha klaster batik Batangan di Kabupaten Batang. Kriteria-kriteria yang menjadi prioritas sampai dengan yang tidak prioritas akan diurai kembali ke dalam alternatif-alternatif dari masing-masing kriteria tersebut.

Kriteria yang menjadi prioritas pengembangan pertama yaitu bahan baku. Kriteria bahan baku terdapat tiga alternatif yang dapat digunakan untuk pengembangan klaster batik Batangan. Ketiga alternatif tersebut dari yang prioritas yaitu pertama akses memperoleh bahan baku dengan persentase sebesar 45,3\%. Kedua kerjasama dengan penyedia bahan baku dengan persentase sebesar 35,2\%. Alternatif ketiga pemberian subsidi untuk bahan baku dengan persentase sebesar $19,5 \%$.

Kriteria yang menjadi prioritas pengembangan kedua yaitu keuangan. Kriteria keuangan terdapat tiga alternatif yang dapat digunakan untuk pengembangan klaster batik Batangan. Ketiga alternatif tersebut dari yang prioritas adalah pertama akses memperoleh pembiayaan usaha dengan persentase sebesar 52,8\%. Alternatif kedua, bantuan untuk usaha dengan persentase sebesar 30,1\%. Alternatif ketiga, pemberian insentif bagi usaha yang aktif dengan persentase sebesar 17,1\%.

Kriteria yang menjadi prioritas pengembangan ketiga yaitu teknologi. Kriteria teknologi terdapat tiga alternatif yang dapat digunakan untuk pengembangan klaster batik Batangan. Ketiga alternatif tersebut dari yang prioritas adalah pertama kemampuan bidang penelitian untuk pengembangan teknologi baru dengan persentase sebesar 56,5\%. Alternatif kedua, pelatihan pemanfaatan teknologi baru dengan persentase sebesar 24,5\%. Alternatif ketiga, bantuan teknologi kepada usaha kecil dengan persentase sebesar 19,1\%.

Kriteria yang menjadi prioritas pengembangan keempat yaitu sumber daya manusia. Kriteria sumber daya manusia memiliki empat alternatif yang dapat digunakan untuk pengembangan klaster batik Batangan. Keempat alternatif tersebut dari yang prioritas yaitu pertama tenaga penyuluh (pendamping) dan konsultasi usaha kecil dengan persentase sebesar 31,9\%. Alternatif kedua, pendidikan dan pelatihan untuk meningkatkan keterampilan teknis dengan persentase sebesar 26,8\%. Alternatif ketiga, pendidikan dan pelatihan untuk meningkatkan pengelolaan usaha dengan persentase sebesar 21\%. Alternatif keempat, pelatihan untuk membudayakan kewirausahaan dengan persentase sebesar $20,2 \%$.

Kriteria yang menjadi prioritas pengembangan kelima yaitu pemasaran. Kriteria pemasaran memiliki tiga alternatif yang dapat digunakan untuk pengembangan klaster batik Batangan. Ketiga alternatif tersebut dari yang prioritas yaitu pertama kemitraan usaha dengan usaha besar dengan persentase sebesar 40,7\%. Alternatif kedua, tempat penjualan dengan persentase sebesar 35,4\%. Alternatif ketiga fasilitas kegiatan pameran dengan persentase sebesar 23,9\%. Hasil olah data AHP secara keseluruhan (overall) dari seluruh alternatif yang ada menunjukkan tiga alternatif paling prioritas. Ketiga alternatif tersebut yaitu pertama akses memperoleh bahan baku yang merupakan alternatif dari kriteria bahan baku dengan persentase sebesar 11.3\%. Kedua, akses memperoleh pembiayaan usaha yang merupakan alternatif dari kriteria keuangan dengan persentase sebesar 10,3\%. Ketiga, kemampuan 
bidang penelitian untuk pengembangan teknologi baru yang merupakan alternatif dari kriteria teknologi dengan persentase sebesar $9,4 \%$.

\section{SIMPULAN}

Hambatan dalam pengembangan klaster batik Batangan mencakup lima aspek yaitu sumber daya manusia, keuangan, pemasaran, bahan baku dan teknologi. Hasil dari analisis PAM menunjukkan klaster batik Batangan memiliki daya saing berdasarkan keunggulan komparatif dan keunggulan kompetitif. Berdasarkan analisis AHP menunjukkan kriteria prioritas pengembangan usaha klaster batik Batangan yaitu bahan baku (nilai bobot o,254), keuangan (nilai bobot o,231), teknologi (nilai bobot 0,211 ), sumber daya manusia (nilai bobot o,193) dan pemasaran (nilai bobot o,111).

Saran dalam penelitian ini bagi pengusaha batik dapat memanfaatkan bahan baku semaksimal mungkin dan diharapkan mampu meningkatkan produksi batik dengan penggunaan input domestik yang lebih selektif.

\section{DAFTAR PUSTAKA}

Anonim. UNESCO Setujui Batik sebagai Warisan Budaya Indonesia. $\quad 7 \quad$ September http://www.antaranews.com/berita/153756/unescosetujui-batik-sebagai-warisan-budayaindonesia.(diakses 7 Februari 2017).

Badan Perencanaan dan Pembangunan Daerah Provinsi Jawa Tengah. 2016. Matrix Evaluasi Program-FedepKlaster-Tahun 2016. Kota Semarang, Jawa Tengah.

BPS Provinsi Jawa Tengah. Jawa Tengah dalam Angka 2015. Kota Semarang: BPS Provinsi Jawa Tengah.

Dian WP, Sucihatiningsih. 2013. Metode analisis Efisiensi Produksi dan Pengambilan Keputusan Pada Bidang Ekonomi Pertanian. Semarang: Unnes Press.

Hartarto, Airlangga. 2004. Strategi Clustering dalam Industrialisasi Indonesia. Yogyakarta. ANDI Publisher.
Lestari, Etty Puji. 2010. Penguatan Ekonomi Industri Kecil dan Menengah melalui Platform Klaster Industri. Jurnal Organisasi dan Managemen, Vol. 6 No.2. September 2010, 146-157.

Pearson, P., C. Gostch dan S. Bahri. 2005. Aplikasi Policy Analysis Matrix pada Pertanian di Indonesia. Jakarta: Yayasan Obor.

Sandriana,Niskha. Abdul Hakim dan Choirul Saleh. 2015. Strategi Pengembangan Produk Unggulan Daerah Berbasis Klaster di Kota Malang. Universitas Brawijaya.Vol. 5, No.1,2015.

Sugiyono. 2010. Metode Penelitian Kuantitatif, Kualitatif dan RED. Bandung:Alfabeta.

Widowati, Amin Retnoningsih dan Sucihatiningsih DWP. 2017. Peningkatan Kualitas, Kuantitas dan Kontinuitas Industri Kertas Handmade. ABDIMAS Vol. 21 No. 1, Juni 2017. 